\title{
Hedgerow effects on $\mathrm{CO} 2$ emissions are regulated by soil type and
} season: implications for carbon flux dynamics in livestock-grazed pasture Ford, Hilary; Healey, John; Webb, Bid; Pagella, Tim; Smith, Andy

\section{Geoderma}

DOI:

https://doi.org/10.1016/j.geoderma.2020.114697

Published: 15/01/2021

Peer reviewed version

Cyswllt i'r cyhoeddiad / Link to publication

Dyfyniad o'r fersiwn a gyhoeddwyd / Citation for published version (APA):

Ford, H., Healey, J., Webb, B., Pagella, T., \& Smith, A. (2021). Hedgerow effects on CO2 emissions are regulated by soil type and season: implications for carbon flux dynamics in livestock-grazed pasture. Geoderma, 382, [114697].

https://doi.org/10.1016/j.geoderma.2020.114697

\footnotetext{
Hawliau Cyffredinol / General rights

Copyright and moral rights for the publications made accessible in the public portal are retained by the authors and/or other copyright owners and it is a condition of accessing publications that users recognise and abide by the legal requirements associated with these rights.

- Users may download and print one copy of any publication from the public portal for the purpose of private study or research.

- You may not further distribute the material or use it for any profit-making activity or commercial gain

- You may freely distribute the URL identifying the publication in the public portal?
}

Take down policy

If you believe that this document breaches copyright please contact us providing details, and we will remove access to the work immediately and investigate your claim. 
Hedgerow effects on $\mathrm{CO}_{2}$ emissions are regulated by soil type and season: implications for

2

3

4

5

6

7

8

9

carbon flux dynamics in livestock-grazed pasture

Hilary Ford*, John R. Healey, Bid Webb, Tim F. Pagella, Andrew R. Smith

School of Natural Sciences, Bangor University, Bangor, LL57 2DG, UK

*Corresponding author e-mail address: hilary.ford@bangor.ac.uk (H. Ford)

\section{Abstract}

In this study we assess the potential for farmland hedgerows to provide climate mitigation via carbon (C) storage, using soil carbon dioxide $\left(\mathrm{CO}_{2}\right)$ efflux to improve upscaling validity. Two contrasting sites, freely-draining (FD) versus seasonally-wet (SW), situated in mixedlivestock farms (Conwy, Wales, UK), were selected. We measured soil $\mathrm{CO}_{2}$ efflux associated with three field boundaries: hedgerow on SW soil; hedgerow on FD soil; stone wall (abiotic control) on FD soil, quantifying the influence of distance from field boundary and grazing occurrence (grazed pasture versus un-grazed zone adjacent to hedgerows) on annual C budgets based on soil $\mathrm{CO}_{2}$ flux and net primary productivity. For the FD site, the annual $\mathrm{C}$ budget showed that pasture was a net source of $\mathrm{C}$ emissions $\left(11 \pm 1.5 \mathrm{t} \mathrm{CO}_{2} \mathrm{ha}^{-1} \mathrm{yr}^{-1}\right)$ and the un-grazed zone adjacent to the hedgerow a net sink $\left(-0.9 \pm 2.2 \mathrm{t} \mathrm{CO}_{2} \mathrm{ha}^{-1} \mathrm{yr}^{-1}\right)$. For the SW site, pasture acted as a small net sink of $\mathrm{C}\left(-0.1 \pm 1.3 \mathrm{t} \mathrm{CO}_{2} \mathrm{ha}^{-1} \mathrm{yr}^{-1}\right)$ and the hedgerow zone a net source $\left(5.8 \pm 0.8 \mathrm{t} \mathrm{CO}_{2} \mathrm{ha}^{-1} \mathrm{yr}^{-1}\right)$, due entirely to a spike in soil $\mathrm{CO}_{2}$ efflux associated with a relatively unusual summer drought. To investigate the effect of this observed summer drought on more typical (for the UK maritime climate) annual C source-sink dynamics, we modelled soil $\mathrm{CO}_{2}$ efflux for a summer-drought-excluded year for both FD and SW soils. With greater hedgerow cover (modelled prediction compared with a baseline of no hedgerows), 
annual $\mathrm{CO}_{2}$ flux became more negative (greater net sink) in fields on FD soil (by $1 \mathrm{t} \mathrm{CO} \mathrm{ha}^{-1}$

$\mathrm{yr}^{-1}$ at $8 \%$ hedgerow cover), with drought limiting the effect size. In SW soils, greater hedgerow cover also led to a more negative annual $\mathrm{CO}_{2}$ flux (by $0.4 \mathrm{t} \mathrm{CO}_{2} \mathrm{ha}^{-1} \mathrm{yr}^{-1}$ at $8 \%$ hedgerow cover) when drought was excluded, but a more positive flux (net C source) with drought included (by $0.5 \mathrm{t} \mathrm{CO}_{2} \mathrm{ha}^{-1} \mathrm{yr}^{-1}$ at $8 \%$ hedgerow cover). This study illustrates the importance of the interaction between soil type and seasonal events such as drought on the ability of hedgerows to act as a net $\mathrm{C}$ sink.

Keywords: Agriculture; Agroforestry; Carbon budget; Carbon dioxide; Grassland; Landscape.

\section{Introduction}

Agricultural activities account for $\sim 15 \%$ of the total global greenhouse gas (GHG) emissions that contribute to climate change (IPCC, 2014). Currently, agriculture is responsible for $\sim 50$ Mt carbon dioxide $\left(\mathrm{CO}_{2}\right)$ equivalent or $10 \%$ of total UK emissions (Defra, 2017), predominantly attributed to the livestock sector. Land management strategies that increase climate change regulation are therefore of major interest to policy makers (Thiel et al., 2015). One such strategy is agroforestry, defined as the practice of growing trees together with livestock and/or crops for a variety of benefits, including silvopasture, riparian planting, shelterbelts and hedgerows (Kim et al., 2016). The potential of existing and new farmland hedgerows, defined as lines of trees and shrubs typically managed by regular cutting (Baudry et al., 2000), to provide climate change mitigation via carbon (C) storage has been increasingly recognised over the past decade (Wolton et al., 2014; Scholefield et al., 2016). Despite this, accurate estimates of hedgerow C storage in temperate agroecosystems are rare, with both aboveand below-ground biomass (Thiel et al., 2015; Axe et al., 2017), soil $\mathrm{CO}_{2}$ efflux (Thiel et al., 2017) and soil organic carbon (SOC) storage (Amadi et al., 2016; Ford et al., 2019) largely 
unknown, or assessed in combination with other agroforestry systems (Ma et al., 2020). Assessment of hedgerow $\mathrm{C}$ budgets at the landscape scale are infrequent and either rely on modelled data (Falloon et al., 2004), focus solely on soil organic carbon (SOC) stock (Walter et al., 2003), or have limited scope for extrapolation to a European setting (Smuckler et al., 2010).

In agroforestry systems, soil $\mathrm{CO}_{2}$ efflux was consistently found to be greater under or adjacent to trees, hedgerows or shelterbelts than within arable cropped or pasture fields further away from the woody plants (Peichl et al., 2006; Amadi et al., 2016; Amadi et al., 2017; BaahAcheamfour et al., 2016; Baah-Achemfour et al., 2017; Thiel et al., 2017), with relatively few studies showing the opposite trend (Franzleubbers et al., 2017). Greater soil $\mathrm{CO}_{2}$ efflux adjacent to trees was attributed to: i) enhanced fine root turnover and rhizodeposition increasing availability of C-rich root exudates for the microbial community (Stevenson et al., 2004; Peichl et al., 2006; Maier et al., 2011), with soil $\mathrm{CO}_{2}$ efflux positively associated with total SOC and particulate organic matter (Bailey et al., 2009); or ii) a modification in the soil physical structure [i.e. a reduction in soil bulk density (Amadi et al., 2016), and decrease in soil moisture content that combine to create aerobic conditions that promote decomposition processes (Amadi et al., 2017)]. In contrast, the soil $\mathrm{CO}_{2}$ efflux in broadleaved or coniferous forests was reduced by up to $20 \%$, compared with neighbouring grassland or pasture (Raich and Tufekcioglu, 2000; Smith and Johnson, 2004; Kellman et al., 2007; Hiltbrunner et al., 2013), attributed largely to a vegetation-mediated reduction in soil temperature (Smith et al., 2003).

In addition to the location of trees in the agricultural environment, silvopastoral carbon storage and soil $\mathrm{CO}_{2}$ efflux are influenced by several factors including soil type, livestock- 
grazing intensity and climatic conditions. SOC is positively associated with soil clay content (Jobbagy and Jackson, 2000), as mineral-associated soil organic matter (SOM) is physically protected from microbial decomposition by adsorption onto silt and clay minerals within the soil (Lavallee et al., 2019). Livestock grazing, particularly in temperate dry-cool climates (aerobic soil), is often associated with increased allocation of plant resources below-ground, with enhanced below-ground biomass and root turnover (Kemp and Michalk, 2007), coupled with 'hotspots' of $\mathrm{CO}_{2}$ emissions from livestock dung (Lin et al., 2009), leading to greater soil $\mathrm{CO}_{2}$ efflux from intensively-grazed than extensively- or un-grazed grasslands (Abdalla et al., 2018). In contrast, livestock-grazing in temperate moist-cool climates, where seasonally water-logged soils (prone to compaction via livestock trampling) are common, promotes anaerobic soil conditions with suppressed $\mathrm{CO}_{2}$ efflux and enhanced $\mathrm{SOC}$ storage (Wiesmeier et al., 2013; Abdalla et al., 2018).

In this study we assess the contribution of hedgerows to annual $\mathrm{C}$ budgets of livestock-grazed pasture land (in the UK maritime climate) on two contrasting soil types, with a particular focus on soil $\mathrm{CO}_{2}$ efflux. We hypothesise that soil $\mathrm{CO}_{2}$ efflux is: i) closely associated with soil temperature, soil moisture (aerobic versus anaerobic conditions) and distance from hedgerow, which is linked to grazing occurrence; ii) influenced more by the presence of a biotic than an abiotic field boundary (via a decrease in soil temperature and moisture close to the hedgerow relative to more distant pasture). In addition, we aim to combine data on soil $\mathrm{CO}_{2}$ efflux with proxies for above- and below-ground net primary productivity to quantify the contribution of hedgerows to annual $\mathrm{C}$ budgets, for a range of hedgerow land cover scenarios (1-8\% cover). 


\subsection{Study area and sampling design}

94

The study area consisted of two sites, located on two tenanted mixed livestock farms (primarily Welsh mountain sheep, with some beef cattle) within the county of Conwy, in Wales, UK, both within the River Conwy catchment. These two sites were chosen to represent two contrasting soil drainage types present within the study catchment (Fig. S1): i) seasonallywet soil (SW) with impeded drainage $\left(53.033457^{\circ},-3.747871^{\circ}\right)$; and ii) free-draining soil (FD) $\left(53.037096^{\circ},-3.712010^{\circ}\right)$, with soils of intermediate drainage excluded. Soils were classified for each site using a combination of the UK Soilscapes soil map, World reference base for soils, and previous field measurements (Table 1): i) SW site - slowly permeable silty-clay stagnosol; and ii) FD site - silty-clay loam cambisol. The two sites were characterised by semiimproved pasture fields with a mixture of productive grass species (e.g. Lolium perenne), in most cases mixed with clover (Trifolium spp., which is $\mathrm{N}$-fixing), forbs and mosses, bordered by either hedgerows or stone walls as typical field boundaries (Fig. S1). Both sites were categorised as poor (low fertility grade 4 or 5) agricultural land (Agricultural Land Classification of England and Wales, 2018). The maritime climate of Conwy (north-west Wales) is characterised by greater rainfall than most UK regions, with mean annual precipitation close to $2,500 \mathrm{~mm}$ (https://www.metoffice.gov.uk/research/climate/maps-anddata/uk-actual-and-anomaly-maps). Conwy air temperatures are generally mid-range for the UK, with mean monthly maximum and minimum temperatures of 12 and $6{ }^{\circ} \mathrm{C}$ respectively.

Three study field boundaries were selected across the two sites (Fig. S1): i) hedgerow on SW soil, ii) hedgerow on FD soil, iii) stone wall (as an abiotic control) on FD soil. Only field boundaries running perpendicular to a slope of consistent gradient ( 5 to $10^{\circ}$ ) were considered 
for selection, with boundaries adjacent to fields with known field drains excluded. Field boundaries were also excluded if there was evidence of bare earth or soil poaching adjacent to the boundary ( $\leq 3 \mathrm{~m}$ perpendicular to the boundary) indicating congregation of livestock (associated with enhanced nutrient inputs and localised compaction). Study plots were located $\geq 5 \mathrm{~m}$ away from gateways or gaps in the boundary through which livestock and vehicles could travel (which are associated with high levels of localised soil compaction). Characteristics of each boundary are summarised in Table 1. For each boundary, one $30 \times 20$ $\mathrm{m}$ study plot was selected, incorporating an area $10 \mathrm{~m}$ upslope and $10 \mathrm{~m}$ downslope of the study boundary (Fig. 1). Three transect lines (10 m apart) were set up within each study plot, running perpendicular to the boundary, with each sampling point referenced relative to the centre of the hedgerow or the edge of the stone wall. At six sampling points along each transect line (three upslope and three downslope, see Fig. 1), cylindrical collars (100 mm diameter, $100 \mathrm{~mm}$ length) for measurement of soil respiration were inserted into the soil to a depth of $50 \mathrm{~mm}$, one month prior to the start of the study. The study design was structured, comparative observational, not experimental or manipulative.

\subsection{Monthly measurements}

Daytime soil $\mathrm{CO}_{2}$ efflux was recorded once per month for one year, from July 2017 to June 2018. Soil respiration from all three boundaries was recorded within 48 hours during similar weather conditions. Soil $\mathrm{CO}_{2}$ efflux was measured at each collar sampling point, after aboveground biomass was clipped to ground level, by a portable $\mathrm{CO}_{2}$ gas analyser, either a $\mathrm{LI}-\mathrm{COR}$ survey system [via a $10 \mathrm{~cm}$ survey chamber (8100-102, LI-COR) attached to the analyser control unit (LI-8100A, LI-COR)] or an EGM-5 [(PP SYSTEMS) attached to a $10 \mathrm{~cm}$ soil respiration chamber (SRC-2, PP SYSTEMS)]. For each month's measurements only one type of 
gas analyser was used for all soil $\mathrm{CO}_{2}$ efflux measurements. These two portable $\mathrm{CO}_{2}$ gas analyser systems were compared under field conditions in agricultural grasslands in the River Conwy catchment equivalent to the present study and found to produce extremely similar results with no significant difference $(p=0.98)$ by Mills et al. (2011). Linear fluxes were calculated using SoilFluxPro (v4.0.1, LI-COR Biosciences). The accuracy of $\mathrm{CO}_{2}(\mathrm{ppm})$ detection in both LI-COR and EGM-5 gas analysers was measured using British Oxygen Company (BOC, UK) standard gases $\left(250,500,1250\right.$ and $\left.2500 \mathrm{CO}_{2} \mathrm{ppm}\right)$. To bring fluxes from each gas analyser in line with the standard gases the following conversions were used for the LI-COR [field measured soil $\mathrm{CO}_{2}$ efflux rate $\left(\mu \mathrm{mol} \mathrm{CO}_{2} \mathrm{~m}^{-2} \mathrm{~s}^{-1}\right) \times 1.04=$ corrected soil $\mathrm{CO}_{2}$ efflux rate $(\mu \mathrm{mol}$ $\left.\mathrm{CO}_{2} \mathrm{~m}^{-2} \mathrm{~s}^{-1}\right)$ ] and EGM-5 [field measured soil $\mathrm{CO}_{2}$ efflux rate $\left(\mathrm{g} \mathrm{CO}_{2} \mathrm{~m}^{-2} \mathrm{~h}^{-1}\right) \times 1.02=$ corrected soil $\mathrm{CO}_{2}$ efflux rate $\left(\mathrm{g} \mathrm{CO}_{2} \mathrm{~m}^{-2} \mathrm{~h}^{-1}\right)$ ]. The EGM-5 corrected soil $\mathrm{CO}_{2}$ efflux rate was converted from $\mathrm{g} \mathrm{CO}_{2} \mathrm{~m}^{-2} \mathrm{~h}^{-1}$ to $\mu \mathrm{mol} \mathrm{CO}_{2} \mathrm{~m}^{-2} \mathrm{~s}^{-1}$ by multiplying the soil $\mathrm{CO}_{2}$ efflux rate $\left(\mathrm{g} \mathrm{CO}_{2} \mathrm{~m}^{-2} \mathrm{~h}^{-1}\right)$ by 6.312.

Adjacent to each sampling point, soil temperature $(10 \mathrm{~cm}$ depth, Checktemp thermometer) and soil moisture content $(0-8 \mathrm{~cm}$ depth, Theta Probe ML2x and Moisture Meter HH2, DeltaT Devices Ltd) were recorded once during each monthly gas-flux sampling occasion.

\subsection{Estimation of C availability}

Soil cores ( $0.15 \mathrm{~m}$ deep, $0.05 \mathrm{~m}$ diameter) for the measurement of SOC stock were sampled once (during autumn) alongside each un-grazed sampling points for both the SW $(n=3)$ and the FD $(n=3)$ hedgerows. Soil cores were also collected in the grazed pasture at $1.2 \mathrm{~m}$ from the boundary fence of the SW and FD hedgerows as part of measurements published in Ford et al. (2019). SOC concentration ( $\mathrm{g} \mathrm{kg}^{-1}$ of dry soil mass) was calculated using the conversion 
an equivalent soil mass (ESM) basis, a layer of $1,000 \mathrm{t} \mathrm{ha}^{-1}$ as in Lee et al. (2009); for a full description of the methods see Ford et al. (2019). Here, SOC stock is expressed on an ESM basis in $\mathrm{kg} \mathrm{C} \mathrm{m}^{-2}$ to allow SOC stock to be compared uncoupled from the influence of soil compaction.

\subsection{Data analysis}

Linear mixed-effects models were used to determine associations between: i) soil $\mathrm{CO}_{2}$ efflux rate and six potential explanatory variables [soil temperature, soil moisture, month, slope position (upslope versus downslope), distance (perpendicular distance from boundary at 0.7 m, $2 \mathrm{~m}$ and $10 \mathrm{~m}$, see Fig. 1) and grazing occurrence (two-level categorical variable incorporating proximity to hedgerow: close-to-hedgerow un-grazed zone at $0.7 \mathrm{~m}$ from the hedgerow from which livestock were excluded by the fence versus further-from-hedgerow grazed pasture at $2 \mathrm{~m}$ or $10 \mathrm{~m}$ from the hedgerow, see Fig. 1)]; ii) soil temperature and four explanatory variables (distance, grazing occurrence, month and slope position); and iii) soil moisture and four explanatory variables (distance, grazing occurrence, month, slope position). These analyses were carried out for soil adjacent to the following three field boundaries: i) SW hedgerow; ii) FD hedgerow; iii) FD stone wall and iv) data from all three field boundaries combined. For all sets of linear mixed-effects models, normal distribution of modelled variables was assessed visually using quantile-quantile plots with variables log transformed to improve fit where necessary. Best model fit was selected on the basis of lowest Akaike Information Criteria (AIC) value. Likelihood-ratio-based pseudo-R-squared values were also calculated for each model, using R package 'MuMIn' (Bartoń, 2018). Results were presented using the ANOVA output of the mixed effects models for ease of interpretation. All statistical analysis was carried out in R (R Core Team, 2018). 
Further analysis was carried out for the growing season of May-September (October-April data excluded), when hedgerows were in full leaf, using a step-wise regression approach. Step-wise regressions 'forwards and backwards' were carried out in the 'MASS' package (Venables and Ripley, 2002) using linear models of i) soil $\mathrm{CO}_{2}$ efflux rate (response variable) and five potential explanatory variables (soil temperature, soil moisture, slope position, distance and grazing occurrence); ii) soil temperature (response variable) and three explanatory variables (slope position, distance and grazing occurrence); iii) soil moisture (response variable) and three explanatory variables (slope position, distance and grazing occurrence). As month influences both soil temperature and moisture it was excluded as an explanatory variable due to potentially confounding effects. This analysis was carried out (using May to September data only) for: i) the SW hedgerow; ii) the FD hedgerow; iii) the FD stone wall; iv) data from all three field boundaries combined. Explanatory variables were only entered into the step-wise regression if hierarchical partitioning (http://cran.rproject.org/package=hier.part) analysis assessed them to have $\geq 5 \%$ independent effects. Results of the stepwise regression displayed a 'final model' selected by lowest AIC, usually with fewer variables than the 'initial model'. From this model the individual contribution of each remaining environmental variable to the overall variation explained was calculated using averages as recommended.

The apparent temperature sensitivity of soil respiration, assumed here to be equivalent to soil $\mathrm{CO}_{2}$ efflux (as in Domínguez et al., 2017), was assessed for: i) SW pasture (further-fromhedgerow, grazed); ii) SW close-to-hedgerow (un-grazed); iii) FD pasture (further-fromhedgerow, grazed); iv) FD close-to-hedgerow (un-grazed); v) data from both hedgerows (i-iv) and stone walls combined, for two scenarios: drought period-included (12 month dataset) 
and drought period-excluded (11 month dataset). Soil respiration (soil $\mathrm{CO}_{2}$ efflux) data were

209

210

211

212

213

214

215

216

217

fitted against soil temperature (at $10 \mathrm{~cm}$ depth) using an exponential function: $\mathrm{SR}=a \mathrm{e}^{b \top}$, where SR is soil respiration, $T$ is soil temperature, and $a$ and $b$ are fitted constants. $Q_{10}$ values (increase in soil respiration per $10{ }^{\circ} \mathrm{C}$ increase in temperature) were calculated as $\mathrm{Q}_{10}=\mathrm{e}^{10 b}$ (Suseela et al., 2012).

\subsection{Annual carbon budgets}

An annual C budget was calculated for two land cover types: i) un-grazed zone close to hedgerows; and ii) livestock-grazed pasture further from hedgerows, on two contrasting soil types, FD (brown earth) and SW (stagnogley). Annual soil $\mathrm{CO}_{2}$ efflux rates were calculated from monthly means (12 months inclusive) for the grazed pasture [10 $\mathrm{m}$ sampling point (mean value of upslope and downslope) perpendicular to field boundary] and the un-grazed zone adjacent to the hedgerow [0.7 $\mathrm{m}$ sampling point (mean value of upslope and downslope) perpendicular to field boundary and protected by the livestock-exclusion fences] for both FD and SW sites and converted into t $\mathrm{CO}_{2} \mathrm{ha}^{-1} \mathrm{yr}^{-1}$. As $\mathrm{CO}_{2}$ efflux was not recorded in December for the SW site, modelled values (using the drought-included $\mathrm{Q}_{10}$ relationship, Table 3) were used to provide realistic data for this site-month combination. Results were expressed as drought period-included (12 month dataset, detailed above) and drought period-excluded [calculated as above but with field-measured soil $\mathrm{CO}_{2}$ efflux rates for the drought period of May and June removed and replaced with modelled values (using the drought-excluded $Q_{10}$ relationship, Table 3) to give a 12-month dataset] scenarios, to illustrate the potential impact of seasonal drought. The two month period May-June 2018 was defined as a drought period in the River Conwy catchment, with a mean Standardized Precipitation Index (SPI) of -1 (Centre for Ecology and Hydrology UK Drought Tool https://eip.ceh.ac.uk/apps/droughts/, 
baseline comparison data 1961-2010), and mean precipitation rate of $<1.5 \mathrm{~mm}$ day $^{-1}$ (based

232 on in-situ weather stations). Over the 20-year 2000-2020 period a May-June drought of similar magnitude was relatively unusual (15\%). In contrast, July-August 2017 was not considered a drought period (as the River Conwy catchment had a mean SPI of 1) despite relatively low soil moisture being recorded on the measurement days for July and August in SW soil in the present study.

Above-ground net primary productivity (ANPP) values for the livestock-grazed pasture and the un-grazed hedgerow zone were taken from the measurements made in semi-improved pasture and broadleaved woodland respectively at other sites in the Conwy River catchment by Smart et al. (2016). Values for fine-root biomass to $15 \mathrm{~cm}$ depth were taken from the measurements made in semi-improved pasture and broadleaved woodland in the Conwy River catchment by Smart et al. (2017) with this depth assumed to account for $100 \%$ of grass and $70 \%$ of hedgerow woody plant fine-root biomass (broadleaved woodland data; Macinnis$\mathrm{Ng}$ et al., 2010) respectively, with fine-root hedgerow woody plant biomass adjusted accordingly (total root biomass $=$ root biomass $0-15 \mathrm{~cm}$ depth $\times 1.3$ ). Below-ground net primary productivity (BNPP) was calculated from the adjusted fine-root biomass, using a root turnover rate of $0.5 \mathrm{yr}^{-1}$ suitable for both grassland and woodland habitats (Gill and Jackson, 2000), and converted to t $\mathrm{CO}_{2} \mathrm{ha}^{-1} \mathrm{yr}^{-1}$. Soil $\mathrm{CO}_{2}$ efflux rates (C source), and ANPP and BNPP (C sinks) were combined to give a comparative flux estimate (either net $\mathrm{C}$ source or sink with a value in $\mathrm{t} \mathrm{CO}_{2} \mathrm{ha}^{-1} \mathrm{yr}^{-1}$ ) for each combination of soil type (SW / FD), cover type (pasture / hedgerow) and drought condition (included / excluded).

\subsection{Scaling up}


To predict the estimated effect of enhanced hedgerow cover on annual $\mathrm{C}$ budgets at a landscape scale, changes in the $\mathrm{CO}_{2}$ flux estimate under a range of greater hedgerow cover scenarios (based on a model 1-ha field) compared with a baseline of $100 \%$ pasture $(0 \%$ hedgerow cover) were calculated. Values for seasonally-wet (SW) versus free-draining (FD) soils under two drought scenarios (included versus excluded, for full description see section 2.5) for either pasture or hedgerow features were extrapolated from net C source / sink value calculations (as in section 2.5) and adjusted according to the relative percentage of pasture and hedgerow cover. For example, a hedgerow density of $50 \mathrm{~m} \mathrm{ha}^{-1}$ with $2 \mathrm{~m}$ width is equivalent to $1 \%$ hedgerow cover ( $99 \%$ pasture cover), reflecting current UK hedgerow density. Hedgerow densities of $200 \mathrm{~m} \mathrm{ha}^{-1}$ (4\% cover) and $400 \mathrm{~m} \mathrm{ha}^{-1}$ (8\% cover) were presented as two possible options on the projected hedgerow cover continuum. For this scaling-up exercise all hedgerows were assumed to be double-fenced to exclude livestock.

\section{Results}

\subsection{Monthly measurements}

Soil $\mathrm{CO}_{2}$ efflux rate was significantly associated with four variables: i) grazing occurrence (positive, $\mathrm{P}<0.001$ ); ii) soil temperature (positive, $\mathrm{P}<0.05$ ); iii) soil moisture (negative, $\mathrm{P}<$ $0.05)$; iv) month $(P<0.001)$, with two significant interaction terms [month $x$ soil temperature $(P<0.001)$ and month $x$ soil moisture $(P<0.001)]$, for the year-long dataset for soil adjacent to all three contrasting field boundaries combined (SW hedgerow, FD hedgerow and FD stone wall). This model explained close to three quarters of the variation in soil $\mathrm{CO}_{2}$ efflux rate $\left(\mathrm{r}^{2}=\right.$

273 0.74). When the three field boundaries were considered separately, soil $\mathrm{CO}_{2}$ efflux was significantly associated with soil temperature, moisture and month for soil adjacent to both the SW and FD hedgerows (Figs. 2a, 3a), with grazing occurrence an additional explanatory 
factor for the FD hedgerow. These combined models explained over $80 \%$ of the variation in soil $\mathrm{CO}_{2}$ efflux $\left(r^{2}=0.82-0.88\right)$. For soil adjacent to the stone wall (FD), $74 \%$ of the variation in soil $\mathrm{CO}_{2}$ efflux was explained by soil temperature and moisture. Apparent temperature sensitivity of soil respiration (soil $\mathrm{CO}_{2}$ efflux) was greater in the livestock-grazed pasture than in the un-grazed zone associated with the hedgerow for both SW and FD sites (Table 2).

Soil temperature was significantly related to both perpendicular distance from boundary and month, for each of the three field boundaries (Figs. 2b, 3b, 4b), with temperature consistently greatest further away from the boundary edge. In addition, for each hedgerow category (SW and FD) soil temperature was positively associated with grazing occurrence. Soil moisture was significantly positively associated with grazing occurrence and with month for each (SW and FD) hedgerow category with 80 and $87 \%$ of variation in soil moisture explained respectively (Figs. 2c, 3c). The main difference was apparent between the un-grazed soil close to the hedgerow inside the boundary fence, which exhibited significantly lower soil moisture content than soil either $2 \mathrm{~m}$ or $10 \mathrm{~m}$ from the hedgerow, in the livestock-grazed part of the field (outside the boundary fence). There was no significant association between soil moisture and distance from boundary for the stone wall control site, which had no fencing (Fig. 4c). Slope position (upslope versus downslope) from the boundary was not significantly associated with soil $\mathrm{CO}_{2}$ efflux rate, soil temperature or soil moisture for either the three field boundary types combined or for each separately.

\subsection{Estimate of SOC stock}

For the FD site SOC stock was very similar between the grazed pasture $\left(6.0 \pm 0.2 \mathrm{~kg} \mathrm{C} \mathrm{m}^{-2}\right)$ and the un-grazed zone adjacent to the hedgerow $\left(6.2 \pm 0.1 \mathrm{~kg} \mathrm{C} \mathrm{m}^{-2}\right)$. For the SW site SOC stock 
was greater adjacent to the hedgerow (un-grazed) than in the grazed pasture $(21 \pm 2$ and 10 $\pm 0.3 \mathrm{~kg} \mathrm{C} \mathrm{m}^{-2}$ respectively).

\subsection{Growing season only}

301

302

303

304

For the growing season (May-September), results were largely in line with those for the annual datasets (section 3.1), with distance from hedgerow/grazing occurrence (grazed versus un-grazed) a significant independent (as assessed by hierarchical partitioning) explanatory variable of soil $\mathrm{CO}_{2}$ efflux, soil temperature and soil moisture for both $\mathrm{SW}$ and $\mathrm{FD}$ hedgerows (Table 3); all increased with distance/grazing (Figs 2 and 3).

\subsection{Annual carbon budgets}

For the FD (brown earth) soil site, the annual $\mathrm{C}$ budget (based on soil $\mathrm{CO}_{2}$ efflux and net primary productivity) showed a marked difference between livestock-grazed pasture and the un-grazed zone adjacent to the hedgerow (Fig. 5), with the pasture acting as a net source of $\mathrm{C}\left(10.8 \pm 1.5 \mathrm{t} \mathrm{CO}_{2} \mathrm{ha}^{-1} \mathrm{yr}^{-1}\right)$ and the hedgerow zone as a net sink $\left(-0.9 \pm 2.2 \mathrm{t} \mathrm{CO}_{2} \mathrm{ha}^{-1} \mathrm{yr}^{-1}\right)$. This result is entirely due to the large reduction in annual soil $\mathrm{CO}_{2}$ efflux rate adjacent to the hedgerow compared with the grazed pasture (of 20.5 and $33.9 \mathrm{t} \mathrm{CO}_{2} \mathrm{ha}^{-1} \mathrm{yr}^{-1}$ respectively). For the drought period-excluded scenario the pasture remained a net source of $C$ of comparative magnitude but the strength of the $C$ sink in the soil adjacent to the hedgerow was increased six-fold to $-6.5 \pm 0.7 \mathrm{t} \mathrm{CO}_{2} \mathrm{ha}^{-1} \mathrm{yr}^{-1}$. For the SW (stagnogley) site, the annual C budget also showed a marked difference between livestock-grazed pasture and the un-grazed zone adjacent to the hedgerow (Fig. 5), but in the opposite direction to the FD site, with the pasture acting as a small net sink of $\mathrm{C}\left(-0.12 \pm 1.3 \mathrm{t} \mathrm{CO}_{2} \mathrm{ha}^{-1} \mathrm{yr}^{-1}\right)$ and the hedgerow as a net source $\left(5.8 \pm 0.8 \mathrm{t} \mathrm{CO}_{2} \mathrm{ha}^{-1} \mathrm{yr}^{-1}\right)$. For the drought period-excluded scenario the pasture 
remained a small net $\mathrm{C}$ sink, with the hedgerow zone reverting from a net source to a large net $\mathrm{C}$ sink $\left(-9.9 \pm 0.3 \mathrm{t} \mathrm{CO}_{2} \mathrm{ha}^{-1} \mathrm{yr}^{-1}\right)$.

\subsection{Scaling up}

With greater hedgerow land-cover, in fields on FD soil the estimated annual $\mathrm{CO}_{2}$ flux became more negative (greater net sink), based on modelled prediction compared with a baseline of no hedgerows, with drought reducing the size of this effect (Fig. 6). In fields on SW soils, greater hedgerow cover also caused a more negative annual $\mathrm{CO}_{2}$ flux estimate under the positive flux (net $\mathrm{C}$ source) under the summer 'drought period-included' scenario (by $\sim 0.5 \mathrm{t}$ $\mathrm{CO}_{2} \mathrm{ha}^{-1} \mathrm{yr}^{-1}$ at $8 \%$ hedgerow cover).

\section{Discussion}

\subsection{Soil $\mathrm{CO}_{2}$ efflux: Temperature, moisture and grazing occurrence}

In this study, soil $\mathrm{CO}_{2}$ efflux was closely associated with soil temperature and soil moisture, but affected more by grazing occurrence (close-to-hedgerow un-grazed zone versus furtherfrom-hedgerow grazed pasture), than distance from hedgerows per se, leading to a partial acceptance of our first hypothesis. Seasonal soil temperature was one of the key abiotic factors regulating soil $\mathrm{CO}_{2}$ efflux in this study, with an increase in soil temperature associated with greater soil $\mathrm{CO}_{2}$ efflux, as expected in temperate ecosystems (Smith et al., 2003). Daytime soil temperatures during the May to September growing season were reduced by 3$5{ }^{\circ} \mathrm{C}$ within the un-grazed zone adjacent to both study hedgerows (Figs. 2, 3), relative to the short-sward pasture, which is likely to be due to the combined sheltering effect of the hedgerow itself and the understorey plant layer. This vegetation-mediated buffering of 
extreme temperatures is well recognised (Stevenson et al., 2004) and largely explains the lower soil $\mathrm{CO}_{2}$ efflux associated with hedgerows for the majority of the year. Annual apparent temperature sensitivity of soil respiration (soil $\mathrm{CO}_{2}$ efflux) was high $\left(\mathrm{Q}_{10}\right.$ values of $5-10$ ) in comparison with the global biome mean of 1.43-2.03 (Zhou et al., 2009), but indicative of ecosystems where seasonality is marked (Domínguez et al., 2017) and $Q_{10}$ values are regulated by vegetation activity (Wang et al., 2010). Here, apparent $Q_{10}$ values were greater in livestock-grazed pasture than in the un-grazed zone adjacent to hedgerows in both contrasting soil types (Table 3) indicating that other variables (e.g. soil moisture) may partially regulate the temperature dependency of soil $\mathrm{CO}_{2}$ efflux adjacent to un-grazed hedgerows.

Soil $\mathrm{CO}_{2}$ efflux was negatively associated with soil moisture content, as is usual in agricultural grasslands (Abdalla et al., 2018), with soil $\mathrm{CO}_{2}$ efflux far greater in FD than SW pasture. Constantly aerobic FD pasture is often associated with greater resource allocation below ground and enhanced fine root turnover, leading to greater soil $\mathrm{CO}_{2}$ efflux than for $\mathrm{SW}$ soils that are periodically anaerobic, where below-ground allocation and turnover are minimised and soil organic C storage is enhanced (Jobbagy and Jackson, 2000; Wiesmeier et al., 2013; Abdalla et al., 2018). Soil moisture was reduced by the presence of hedgerows, with effects most marked within the 2-m un-grazed zone associated with the hedgerow itself, due to a probable combination of woody plant roots extracting soil moisture from the soil (Kowalchuk and de Jong, 1995) and an enhanced water infiltration rate due to the absence of grazing compaction (Marshall et al., 2009). Recent evidence shows that soil moisture levels moderate the temperature dependency of soil $\mathrm{CO}_{2}$ efflux (Lellei-Kovacs et al., 2016), particularly at soil temperatures $>10^{\circ} \mathrm{C}$, common during spring and summer in UK uplands. During the initial summer drought-period, the $\mathrm{CO}_{2}$ efflux of SW soils was much greater in the recently dry ungrazed hedgerow zone than in the relatively wetter pasture, despite a soil temperature 
illustrates the importance of incorporating soil moisture into predictive models of soil $\mathrm{CO}_{2}$ efflux.

Soil $\mathrm{CO}_{2}$ efflux was positively correlated with the occurrence of livestock grazing in this study, with effects particularly noticeable for the growing season. This grazing effect can be explained partly by the influence of livestock on soil temperature-moisture dynamics (as detailed above), but the independent grazing effects identified (Table 4) may be due to preferential allocation of plant resources below-ground (Kemp and Michalk, 2007) and/or $\mathrm{CO}_{2}$ emissions from livestock dung (Lin et al., 2009). In addition, grazing occurrence was a stronger indicator of soil $\mathrm{CO}_{2}$ efflux than distance from hedgerow, indicating a swift transition between the un-grazed zone associated with the study hedgerows and grazed pasture at the hedgerow livestock-exclusion fence, particularly in FD soil (Fig. 3). It is possible that soil $\mathrm{CO}_{2}$ efflux was also influenced by broad differences in root exudate $C$ sources available to the soil microbial community (Stevenson et al., 2004) based on the proximity of sample points to woody or pasture plants, but this was not measured directly.

\subsection{Biotic versus abiotic field boundaries}

Soil $\mathrm{CO}_{2}$ efflux was influenced more by the presence of a biotic than an abiotic field boundary, with the un-grazed zone associated with the hedgerow characterised by lower soil temperature and soil moisture relative to more distant pasture, supporting our third hypothesis. Summer soil temperature was reduced, but only by $\leq 1{ }^{\circ} \mathrm{C}$, in the immediate vicinity of the stone wall (Fig. 4), illustrating the difference between biotic and abiotic field boundaries in their buffering of soil temperature and thus regulation of soil $\mathrm{CO}_{2}$ efflux. 
(Kovář et al., 2011; Rodrigo-Comino et al., 2019) this type of abiotic field boundary did not influence soil moisture dynamics in the present study.

\subsection{Carbon budgets}

392

393

394

Annual $\mathrm{C}$ budgets of hedgerows and livestock-grazed pasture, on two contrasting soil types typical of UK uplands, were calculated by combining data on soil $\mathrm{CO}_{2}$ efflux with proxies for above- and below-ground net primary productivity. In this study, livestock-grazed pastures acted as a small net C sink in SW soil and a net source in FD soil, in line with the results of Abdalla et al. (2018), with the drought period having only a minimal effect on carbon sinksource dynamics. Hedgerows, including the soil of their adjacent un-grazed zones, were net C sinks under the drought period-excluded scenario, storing 6-10 t $\mathrm{CO}_{2} \mathrm{ha}^{-1} \mathrm{yr}^{-1}$ (Fig. 5), which is substantially lower than the $15-40 \mathrm{t} \mathrm{CO}_{2} \mathrm{ha}^{-1} \mathrm{yr}^{-1}$ stored in agroforestry systems according to a review of $C$ budgets (Kim et al., 2016), although this review included a broad range of agroforestry types and did not include hedgerows specifically. Under the drought periodincluded scenario, hedgerows remained a net, though smaller in magnitude, $\mathrm{C}$ sink in FD soil (of $\sim 1 \mathrm{t} \mathrm{CO}_{2} \mathrm{ha}^{-1} \mathrm{yr}^{-1}$ ) but became a net $\mathrm{C}$ source in SW soil $\left(\sim 6 \mathrm{t} \mathrm{CO}_{2} \mathrm{ha}^{-1} \mathrm{yr}^{-1}\right)$ due to a doubling of $\mathrm{CO}_{2}$ efflux (relative to the drought-excluded scenario). This huge spike in soil $\mathrm{CO}_{2}$ efflux in SW soil occurred entirely within the first month of the drought period and coincided with a sudden switch from moist-cool to dry-warm soil conditions. This mirrors the transition from flooded to non-flooded conditions in forested wetland and seasonally flooded forests (Miao et al., 2013; Barbosa et al., 2017), where newly aerobic soil stimulates root growth and decomposition of SOM (including necromass accumulated via root death during anaerobic period), enhancing autotrophic/microbial respiration and subsequent $\mathrm{CO}_{2}$ efflux (Peichl et al., 2006; Amadi et al., 2017). 
Here, we assessed the potential for farmland hedgerows to provide climate change mitigation via carbon storage, attempted previously by Falloon et al. (2004), using measured soil $\mathrm{CO}_{2}$ efflux to improve the validity of upscaling. At present total UK hedgerow land cover is $\sim 400,000 \mathrm{~km}$ (Elliot et al., 2014; Scholefield et al., 2016), equivalent to $50 \mathrm{~m} \mathrm{ha}^{-1}$ across the whole agricultural land area. At this level ( $1 \%$ land cover) the impact of hedgerows on the C budget at a landscape scale was minimal for both FD and SW soils. However, the capacity of the farmland landscape to act as a C sink was enhanced by increased hedgerow cover (in scenarios up to $8 \%$ cover). This effect is in accord with previous studies of pastures in Europe and USA, where a positive contribution of hedgerows to SOC storage was reported (Walter et al., 2003; Smuckler et al., 2010; Lacoste et al., 2015). Although this pattern holds for both soil types under the drought period-excluded scenario, the capacity for hedgerows to contribute to a net $\mathrm{C}$ sink at the landscape scale was reversed in SW soil during periods of drought (Fig. 6); in these conditions increased hedgerow cover resulted in greater $C$ emissions. Although informative, with potentially important implications for $\mathrm{C}$ storage capacity, data for the earlysummer drought scenario are from only 2 months duration, associated with a relatively unusual climatic event for the UK maritime conditions, and should therefore be extrapolated with caution. Relative abundance of soil types is also relevant to this upscaling exercise. If we exclude peat soils [where neither livestock-grazing or tree-planting is advised (Ostle et al., 2009)], FD and SW (including impeded drainage) soil types each equate to approximately one half of Welsh upland land-cover respectively (Hallett et al., 2017). However, as this approach amalgamates related soils into two broad categories on the basis of drainage, future work could take a more nuanced approach by studying pasture-hedgerow dynamics across a wider range of UK or upland soil types. 
437 Carbon budgets were modelled for a range of hedgerow land cover scenarios (1-8\%), either 438 including or excluding the effect of a naturally-occurring early-summer drought period. Under 439 the drought-excluded scenario, the un-grazed zone adjacent to hedgerows acted as a net C sink in both the contrasting soil types, allowing an increase in C stored with greater hedgerow cover. Taken in isolation this result could be used as evidence to promote hedgerow planting on agricultural land, regardless of soil type, in an attempt to meet climate change mitigation targets via $\mathrm{C}$ storage. However, during drought conditions, hedgerow-associated soil $\mathrm{CO}_{2}$ efflux increased markedly, effectively 'pausing' the effect of hedgerow cover as a C storage mechanism. Moreover, on the SW soils characteristic of some upland farms in the UK (Hallett et al., 2017), the sudden change in soil temperature and moisture dynamics associated with a drought period triggered a spike in $\mathrm{CO}_{2}$ efflux that turned hedgerows into a net annual $\mathrm{C}$ source. As a result, greater hedgerow cover (up to $8 \%$ ) could potentially increase net C emissions, although our evidence base for this conclusion is limited. Our study illustrates the importance of considering the impact of soil type and seasonal extreme events such as drought on the capacity of hedgerows to act as a net $\mathrm{C}$ sink, with clear implications for policy makers and land managers tasked with meeting the objective of minimising the net $\mathrm{CO}_{2}$ emissions from farmland.

\section{Acknowledgements}

All authors acknowledge the financial support provided by the Welsh Government and Higher Education Funding Council for Wales through the Sêr Cymru National Research Network for Low Carbon, Energy and Environment. Thanks are also due to the National Trust and the Fferm Ifan group who allowed access to their land. 
460 Abdalla, M., Hastings, A., Chadwick, D.R., Jones, D.L., Evans, C.D., Jones, M.B., Rees, R.M., \& 461 Smith, P. (2018). Critical review of the impacts of grazing intensity on soil organic carbon 462 storage and other soil quality indicators in extensively managed grasslands. Agriculture, 463 Ecosystems and Environment, 253, 62-81.

464 Elliot, J., Evans, C., Moxley, J., Chadwick, D., Steve, A., Durrant, C., Moorby, J., Misslebrook, T., 465 Smith, S., Styles, D., \& Jones, D. (2014). Review of land use climate change: An assessment of 466 the evidence base for climate change action in the agriculture, land use and wider foodchain 467 sectors in Wales. ADAS UK Ltd., Leeds, U.K., 151pp. (CEH Project no: NEC05228).

468 Agricultural Land Classification of England and Wales (2018). 469 https://beta.gov.wales/sites/default/files/publications/2018-02/agricultural-land470 classification-frequently-asked-questions.pdf.

471 Amadi, C.C., Van Rees, C.J., \& Farrell, E. (2016). Soil-atmosphere exchange of carbon dioxide, 472 methane and nitrous oxide in shelterbelts compared with adjacent cropped fields. 473 Agriculture, Ecosystems and Environment, 223, 123-134.

474 Amadi, C.C., Farrell, R.E., \& Van Rees, K.C.J., (2017). Greenhouse gas emissions along a 475 shelterbelt-cropped field transect. Agriculture, Ecosystems and Environment, 241, 110-120.

476 Axe, M.S., Grange, I.D. \& Conway, J.S., (2017). Carbon storage in hedge biomass - A case study 477 of actively managed hedges in England. Agriculture, Ecosystems and Environment, 250, 81478 88. 
Baah-Acheamfour, A., Carlyle, C.N., Lim, S-S., Bork, E.W., \& Chang, S.X. (2016). Forest and grassland cover types reduce net greenhouse gas emissions from agricultural soils. Science of the Total Environment, 571, 1115-1127.

Baah-Achemfour, M., Chang, S.X., Bork, E.W. \& Carlyle, C.N. (2017). The potential of agroforestry to reduce atmospheric greenhouse gases in Canada: Insight from pairwise comparisons with traditional agriculture, data gaps and future research. The Forestry Chronicle, 93, 180-189.

Bailey, N.J., Motavalli, P.P., Udawatta, R.P., \& Nelson, K.A. (2009). Soil $\mathrm{CO}_{2}$ emissions in 487 agricultural watersheds with agroforestry and grass contour buffer strips. Agroforestry Systems, 77, 143-158.

Barbosa, R.I., Volkmer de Castilho, C., de Oliveira Perdiz, R., Damasco, G., Rodrigues, R., \& Fearnshide, P.M. (2017). Decomposition rates of coarse woody debris in undisturbed Amazonian seasonally flooded and unflooded forests in the Rio Negro-Rio Branco Basin in Roraima, Brazil. Forest Ecology and Management, 397, 1-9.

Bartoń, K. (2018). MuMIn: Multi-Model Inference. https://cran.r-

project.org/web/packages/MuMIn/MuMln.pdf. origin, function and management. Journal of Environmental Management, 60, 7-22.

Defra (2017). Agricultural statistics and climate change. Department for Environment, Food

Affairs. 
501

502

503

504

505

506

507

508

509

510

511

512

513

514

515

516

517

518

519

520

521

Domínguez, M.T., Smith, A.R., Reinsch, S. \& Emmett, B.A. (2017). Inter-annual variability of soil respiration in wet shrublands: do plants modulate its sensitivity to climate? Ecosystems, $20,796-812$

Falloon, P., Powlson, D. \& Smith, P. (2004). Managing field margins for biodiversity and carbon sequestration: a Great Britain case study. Soil Use and Management, 20, 240-247.

Ford, H., Healey, J.R., Webb, B., Pagella, T.F. \& Smith, A.R. (2019). How do hedgerows influence soil organic carbon stock in livestock-grazed pasture? Soil Use and Management, doi: $10.1111 /$ sum.12517.

Franzleubbers, A.J., Chappell, J.C., Shi, W. \& Cubbage, F.W. (2017). Greenhouse gas emissions in an agroforestry system of the southeastern USA. Nutrient Cycling in Agroecosystems, 108, 85-100.

Gill, R.A., \& Jackson, R.B. (2000). Global patterns of root turnover for terrestrial ecosystems. New Phytologist, 147, 13-31.

Grömping, U. (2006). Relative importance for linear regression in R: the package relaimpo. Journal of Statistical Software, 17, 1-27.

Hallett, S.H., Sakrabani, R., Keay, C.A. \& Hannam, J.A. (2017). Developments in land information systems: examples demonstrating land resource management capabilities and options. Soil Use and Management, 33, 514-529.

Hiltbrunner, D., Zimmermann, S. \& Hagedorn, F. (2013). Afforestation with Norway spruce on a subalpine pasture alters carbon dynamics but only moderately affects soil carbon storage. Biogeochemistry, 115, 251-266. 
IPCC (2014). Climate Change 2014: Synthesis Report. Contribution of Working Groups I, II and

523

524

525

526

527 III to the Fifth Assessment Report of the Intergovernmental Panel on Climate Change [Core Writing Team, R.K. Pachauri and L.A. Meyer (eds.)]. IPCC, Geneva, Switzerland, 151 pp.

Jobbagy, E.G. \& Jackson, R.B. (2000). The vertical distribution of soil organic carbon and its relation to climate and vegetation. Ecological Applications, 10, 423-436.

Kellman, L., Beltrami, H. \& Risk, D. (2007). Changes in seasonal soil respiration with pasture conversion to forest in Atlantic Canada. Biogeochemistry, 82, 101-109.

Kemp, D.R. \& Michalk, D.L. (2007). Towards sustainable grassland and livestock management. Journal of Agricultural Science, 145, 543-564.

Kim, D-G., Kirschbaum, M.U.F., \& Beedy, T.L. (2016). Carbon sequestration and net emissions of $\mathrm{CH}_{4}$ and $\mathrm{N}_{2} \mathrm{O}$ under agroforestry: Synthesizing available data and suggestions for future studies. Agriculture, Ecosystems and Environment, 226, 65-78.

Kovář, P., Vaššová, D. \& Hrabalíková, M. (2011). Mitigation of surface runoff and erosion impacts on catchment by stone hedgerows. Soil and Water Research, 6, 5-16.

Kowalchuk, T.E., \& de Jong, E. (1995). Shelterbelts and their effect on crop yield. Canadian Journal of Soil Science, 75, 543-550.

Lacoste, M., Viaud, V., Michot, D. \& Walter, C. (2015). Landscape-scale modelling of erosion processes and soil carbon dynamics under land-use and climate change in agroecosystems. European Journal of Soil Science, 66, 780-791.

Lavallee, J.M., Soong, J.L., \& Cotrufo, M.F. (2019) Conceptualizing soil organic matter into particulate and mineral-associated forms to address global change in the $21^{\text {st }}$ century. Global Change Biology, 26, 261-273. 
Lee, J., Hopmans, J. W., Rolston, D. E., Baer, S. G., \& Six, J. (2009). Determining soil carbon stock changes: simple bulk density corrections fail. Agriculture, Ecosystems and Environment, $134,251-256$.

547

Lellei-Kovács, E., Botta-Dukát, Z., de Dato, G., Estiarte, M., Guidolotti, G., Kopittke, G.R., Kovács-Láng, E., Kröel-Dulay, G., Larsen, K.S., Peñuelas, J., Smith, A.R., Sowerby, A., Tietema, A., \& Schmidt, I.K. (2016). Temperature Dependence of Soil Respiration Modulated by Thresholds in Soil Water Availability Across European Shrubland Ecosystems. Ecosystems, 19, 1460-1477.

552

Lin, X., Wang, S., Ma, X., Xu, G., Luo, C., Li, Y., Jiang, G., \& Xie, Z. (2009). Fluxes of $\mathrm{CO}_{2}, \mathrm{CH}_{4}$ and $\mathrm{N}_{2} \mathrm{O}$ in an alpine meadow affected by yak excreta on the Qinghai-Tibetan plateau during summer grazing periods. Soil Biology and Biochemistry, 41, 718-725.

Ma, Z., Chen, H.Y.H., Bork, E.W., Carlyle, C.N. \& Chang, S.X. (2020). Carbon accumulation in agroforestry systems is affected by tree species diversity, age and regional climate: A global meta-analysis. Global Ecology and Biogeography, DOI: 10.1111/geb.13145 models. Agricultural and Forest Meteorology, 151, 1723-1730. Solloway, I., Wheater, H.S. \& Chell, J. (2009). The impact of upland land management on flooding: results from an improved pasture hillslope. Hydrological Processes, 23, 464-475. I., Zeppel, J.B., \& Eamus, D. (2010). Root biomass distribution and soil properties of an open woodland on a duplex soil. Plant and Soil, 327, 377-388. 
567 The effect of water table fluctuation on soil respiration in a lower coastal plain forested wetland in the southeastern U.S. Journal of Geophysical Research Biogeosciences, 118, 17481762.

570

Mills, R., Glanville, H., McGovern, S., Emmett, B., \& Jones, D.L. (2011). Soil respiration across three contrasting ecosystem types: comparison of two portable IRGA systems. Journal of Plant Nutrition and Soil Science, 174, 532-535.

573 Ostle, N.J., Levy, P.E., Evans, C.D., \& Smith, P. (2009) UK land use and soil carbon sequestration. Land Use Policy, 26, 274-283.

Peichl, M., Thevathasan, N.V., Gordon, A.M., Huss, J., \& Abohassan, R.A. (2006). Carbon sequestration potentials in temperate tree-based intercropping systems, southern Ontario,

577 Canada. Agroforestry Systems, 66, 243-257.

R Core Team (2018). R: A language and environment for statistical computing. R Foundation

579 for Statistical Computing, Vienna, Austria. URL https://www.R-project.org/.

Raich, J.W., \& Tufekcioglu, A. (2000). Vegetation and soil respiration: Correlations and controls. Biogeochemistry, 48, 71-90. (2019). Rainfall-simulated quantification of initial soil erosion processes in sloping and poorly maintained terraced vineyards - Key issues for sustainable management systems. Science of the Total Environment, 660, 1047-1057. 

of the extent and distribution of woody linear features in rural Great Britain. Ecology and Evolution, 6, 8893-8902.

Smart, S.M., Reinsch, S., Mercado, L., Blanes, M.C., Cosby, B.J., Glanville, H.C., Jones, D.L., 590 Marshall, M.R., \& Emmett, B.A. (2017). Plant aboveground and belowground standing biomass measurements in the Conwy catchment in North Wales (2013 and 2014). NERC

Environmental Information Data Centre. https://doi.org/10.5285/46bb0117-ed5d-4167a375-d84d1237cf21

Smart, S.M., Reinsch, S., Mercado, L., Blanes, M.C., Cosby, B.J., Glanville, H.C., Jones, D.L., Marshall, M.R., \& Emmett, B.A. (2016). Plant structural measurements in North Wales and 596 Northwest England 2013 and 2014. NERC Environmental Information Data Centre. https://doi.org/10.5285/8899768c-cc5a-4885-a88b-c08374ee568e Smith, D.L., \& Johnson, L. (2004). Vegetation-mediated changes in microclimate reduce soil respiration as woodlands expand into grasslands. Ecology, 85, 3348-3361. greenhouse gases between soil and atmosphere: interactions of soil physical factors and 602 biological processes. European Journal of Soil Science, 54, 779-791. in an organic farmscape. Agriculture, Ecosystems and Environment, 139, 80-97. 

and forest soil microbial communities show distinct patterns in their catabolic respiration responses at a landscape scale. Soil Biology and Biochemistry, 36, 49-55.

Suseela, V., Conant, R.T., Wallenstein, M.D., \& Dukes, J.S. (2012). Effects of soil moisture on 610 the temperature sensitivity of heterotrophic respiration vary seasonally in an old-field climate change experiment. Global Change Biology, 18, 336-48.

612

Thiel, B., Smukler, S.M., Krzic, M., Gergel, S., \& Terpsma, C. (2015). Using hedgerow biodiversity to enhance the carbon storage of farmland in the Fraser River delta of British Columbia. Journal of Soil and Water Conservation, 70, 247-256.

Thiel, B., Krzic, M., Gergel, S., Terpsma, C., Black, A., Jassal, R., \& Smukler, S.M. (2017). Soil $\mathrm{CO}_{2}, \mathrm{CH}_{4}$ and $\mathrm{N}_{2} \mathrm{O}$ emissions from production fields with planted and remnant hedgerows in the Fraser river delta of British Columbia. Agroforestry Systems, 91, 1139-1156.

Venables, W.N., \& Ripley, B.D. (2002). Modern applied statistics with S. Fourth Edition. Springer, New York. ISBN 0-387-95457-0.

Walter, C., Merot, P., Layer, B., \& Dutin, G. (2003). The effect of hedgerows on soil organic carbon storage in hillslopes. Soil Use and Management, 19, 201-207. ecological gradients in seasonal $\mathrm{Q}_{10}$ of soil respiration explained by climate or by vegetation seasonality. Soil Biology and Biochemistry, 42, 1728-1734. B., von Lützow, M., \& Kögel-Knabner, I. (2013). Amount, distribution and driving factors of soil 

organic carbon and nitrogen in cropland and grassland soils of southeast Germany (Bavaria).

628 Agriculture, Ecosystems and Environment, 176, 39-52.

629 Wolton, R., Pollard, K., Goodwin, A., \& Norton, L. (2014). Regulatory services delivered by 630 hedges: The evidence base. Report of Defra project LM0106. 99pp.

631 Zhou, T., Shi, P., Hui, D., \& Luo, Y. (2009). Global pattern of temperature sensitivity of soil 632 heterotrophic respiration $\left(Q_{10}\right)$ and its implications for carbon-climate feedback. Journal of 633 Geophysical Research, 114, G02016, doi:10.1029/2008JG000850.

634 
636 Table 1. Characteristics of the two contrasting soil types in this study.

\begin{tabular}{lll}
\hline Soil type $^{1}$ & Seasonally-wet (SW) & Free-draining (FD) \\
\hline Soil classification (UK) & Stagnogley & Brown earth \\
Soil classification (Worldwide) ${ }^{3}$ & Stagnosol & Cambisol \\
Soil texture & Silty-clay & Silty-clay loam \\
Sand / silt / clay $(\%)^{3}$ & $0-20 / 40-60 / 40-60$ & $0-20 / 40-73 / 27-40$ \\
$\mathrm{pH}^{4}$ & $5.7 \pm 0.1$ & $5.5 \pm 0.1$ \\
$\mathrm{Bulk}^{4}$ density $\left(\mathrm{g} \mathrm{cm}^{-3}\right)^{4}$ & $0.64 \pm 0.04$ & $0.89 \pm 0.04$ \\
${ }^{1}$ As referred to in this paper & & \\
${ }^{2}$ UK Soilscapes soil map (http://www.landis.org.uk/soilscapes/) & \\
${ }^{3}$ World reference base for soils (WRB; http://www.fao.org/soils-portal/soil-survey/soil-classification/world- \\
reference-base/en/; http://www.fao.org/3/i3794en/l3794en.pdf) \\
${ }^{4}$ Field measurements $<10$ m from study sites (Ford et al., 2019) \\
\end{tabular}


646 location see Fig. S1.

\begin{tabular}{|c|c|c|c|}
\hline Boundary & SW Hedgerow & FD Hedgerow & FD Stone wall \\
\hline \multicolumn{4}{|l|}{ Site characteristics } \\
\hline Location & SW site & FD site & FD site \\
\hline Soil type & Stagnogley & Brown earth & Brown earth \\
\hline Drainage & Seasonally-wet, impeded & Free-draining & Free-draining \\
\hline Slope & Shallow $\left(\sim 5^{\circ}\right)$ & Steep $\left(\sim 10^{\circ}\right)$ & Steep $\left(\sim 10^{\circ}\right)$ \\
\hline Grazing & $\begin{array}{l}\text { Sheep all year, cattle } \\
\text { (May-June) }\end{array}$ & $\begin{array}{l}\text { Sheep all year, cattle } \\
\text { (March-November) }\end{array}$ & $\begin{array}{l}\text { Sheep all year, cattle } \\
\text { (March-November) }\end{array}$ \\
\hline Pasture & $\begin{array}{l}\text { Semi-improved grass with } \\
\text { patches of Juncus spp. }\end{array}$ & Semi-improved & Semi-improved \\
\hline Silage cut ${ }^{1}$ & $\begin{array}{l}\text { Yes (but not during study } \\
\text { period due to drought) }\end{array}$ & No & No \\
\hline \multicolumn{4}{|l|}{ Boundary characteristics } \\
\hline Hedgerow composition & $\begin{array}{l}\text { Prunus spinosa (60\%), } \\
\text { Corylus avellana (40\%) }\end{array}$ & $\begin{array}{l}\text { Crataegus monogyna } \\
(70 \%), \text { P. spinosa }(15 \%) \\
\text { C. avellana (15\%) }\end{array}$ & $n a$ \\
\hline Hedgerow understory & $\begin{array}{l}\text { Urtica dioica, Galium } \\
\text { aparine }\end{array}$ & $\begin{array}{l}\text { U. dioica, Cirsium } \\
\text { vulgare, Ranunculus } \\
\text { repens }\end{array}$ & na \\
\hline Management & Biennially cut, $\mathrm{H} \sim 2 \mathrm{~m}$ & Biennially cut, $\mathrm{H} \sim 2 \mathrm{~m}$ & na \\
\hline Age & 40 years & 10 years & In situ 100 years \\
\hline Size & $W=2 m, H=2 m$ & $W=1 m, H=2 m$ & $\mathrm{~W}=0.6 \mathrm{~m}, \mathrm{H}=1.2 \mathrm{~m}$ \\
\hline Fence & Double $^{2}, 2 \mathrm{~m}$ wide & Double $^{2}, 2 \mathrm{~m}$ wide & na \\
\hline
\end{tabular}

$647 \quad \mathrm{SW}=$ seasonally-wet soil, $\mathrm{FD}=$ free-draining soil

$648 \mathrm{~W}=$ width, $\mathrm{H}=$ height, $n a=$ non-applicable

$649{ }^{1}$ Silage cut refers to annual management where semi-improved pasture is routinely cut and removed for use as 650 silage (winter animal feed).

651 '2Double fenced at $2 \mathrm{~m}$ wide refers to the total width of the livestock exclusion zone across both sides of the 652 hedgerow (see Fig. 1). 
653 Table 3. Apparent temperature sensitivity of soil respiration (soil $\mathrm{CO}_{2}$ efflux) expressed as $\mathrm{Q}_{10}$ 654 values for both grazed $(G)$ pasture and the un-grazed $(U)$ zone adjacent to the hedgerow on 655 both seasonally-wet (SW, stagnogley) and free-draining (FD, brown earth) soils. Two 656 scenarios, drought period-included (12-month dataset) and drought period-excluded (10 657 months with May and June removed) are presented.

658

\begin{tabular}{lllll}
\hline & \multicolumn{2}{l}{ Drought included } & \multicolumn{2}{l}{ Drought excluded } \\
& $\mathrm{Q}_{10}$ & $\mathrm{R}^{2}$ & $\mathrm{Q}_{10}$ & $\mathrm{R}^{2}$ \\
\hline SW pasture (G) & 10.3 & 0.58 & 8.4 & 0.58 \\
SW hedgerow (U) & 7.4 & 0.42 & 5.7 & 0.58 \\
FD pasture (G) & 7.2 & 0.83 & 6.4 & 0.81 \\
FD hedgerow (U) & 5.3 & 0.51 & 5.0 & 0.65 \\
\hline
\end{tabular}

659

660 
Table 4. Best fit models of soil $\mathrm{CO}_{2}$ efflux, temperature and moisture for soils adjacent to three contrasting field boundary categories, two fenced hedgerows (inside fence, un-grazed at 0.7 $\mathrm{m}$ from hedgerow; outside fence, livestock-grazed pasture at $2 \mathrm{~m}$ and $10 \mathrm{~m}$ ) on seasonallywet and free-draining soil respectively and one stone wall (livestock-grazed pasture at $0.7 \mathrm{~m}$, outputs of step-wise regression models are presented with explanatory variable information. boundary.

\begin{tabular}{llllllll}
\hline Boundary type & Response & Explanatory v1 & Explanatory v2 & Explanatory v3 & F & Sig & $\mathrm{R}^{2}$ \\
\hline All $(\mathrm{n}=265)$ & SR & SM $(30 \%)$ & G/U (40\%) & ST (30\%) & 25.7 & $* * *$ & 0.23 \\
SW Hedgerow & SR & SM (64\%) & G/U (36\%) & - & 9.72 & $* * *$ & 0.18 \\
FD Hedgerow & SR & SM (8\%) & G/U (92\%) & - & 41.5 & $* * *$ & 0.49 \\
FD Stone wall & SR & ST (100\%) & - & - & 7.73 & $* *$ & 0.08 \\
All ( $=265)$ & ST & G/U (100\%) & - & n/a & 59.8 & $* * *$ & 0.18 \\
SW Hedgerow & ST & D (100\%) & - & n/a & 14.73 & $* * *$ & 0.15 \\
FD Hedgerow & ST & G/U (100\%) & - & n/a & 20.7 & $* * *$ & 0.19 \\
All (n = 265) & SM & G/U (69\%) & D (31\%) & n/a & 14.57 & $* * *$ & 0.10 \\
SW Hedgerow & SM & G/U (100\%) & - & n/a & 88.6 & $* * *$ & 0.50 \\
FD Hedgerow & SM & G/U (100\%) & - & n/a & 14.0 & $* * *$ & 0.14 \\
\hline
\end{tabular}
draining soil, $\mathrm{SR}=$ soil $\mathrm{CO}_{2}$ efflux, $\mathrm{ST}=$ soil temperature, $\mathrm{SM}=$ soil moisture, $\mathrm{G} / \mathrm{U}=$ grazed/un-grazed categorical variable, $D=$ distance from boundary $(0.7 \mathrm{~m}, 2 \mathrm{~m}$ or $10 \mathrm{~m})$. (\%) associated with v1, v2 and v3 values refers to \% 
676 Fig. 1. Sampling schematic for biotic (hedgerow) and abiotic (stone wall) boundaries. SW = 677 seasonally-wet soil, FD = free-draining soil. The upslope and downslope parts of each transect 678 start from the centre of the hedgerow or directly adjacent to the edge of the stone wall. The area adjacent to hedgerows within the livestock-exclusion boundary fence is un-grazed.

Fig. 2. Monthly measurements of soil adjacent to a hedgerow on seasonally-wet soil for a) soil $\mathrm{CO}_{2}$ efflux, b) soil temperature and c) soil moisture at three perpendicular distances from the hedgerow [0.7 $\mathrm{m}$ (un-grazed); $2 \mathrm{~m}$ (grazed); $10 \mathrm{~m}$ (grazed)]. The $\mathrm{r}^{2}$ value of the proportion of variation explained is given for the best-fit mixed effects model, with explanatory variable(s) and interaction terms listed underneath. For panel $b$, letters $(x, y, z)$ adjacent to lines denote significant differences between the three distance categories included in the legend (there were no significant differences with distance for panels a and c). ${ }^{* * *}=P<0.001$, Temperature = soil temperature, Moisture $=$ soil moisture, Grazing = grazing occurrence (yes/no), Distance = perpendicular distance from hedgerow, $\mathrm{M}=$ month, $\mathrm{x}=$ interaction between variables. Monthly means for each distance are presented with error bars showing the standard error of the mean $(n=3)$. The grey shaded box indicates period of drought.

Fig. 3. Monthly measurements of soil adjacent to a hedgerow on free-draining soil for a) soil $\mathrm{CO}_{2}$ efflux, b) soil temperature and c) soil moisture at three perpendicular distances from the hedgerow [0.7 $\mathrm{m}$ (un-grazed); $2 \mathrm{~m}$ (grazed); $10 \mathrm{~m}$ (grazed)]. The $\mathrm{r}^{2}$ value of the proportion of variation explained is given for the best-fit mixed effects model, with explanatory variable(s) listed underneath. For panel $b$, letters $(x, y, z)$ adjacent to lines denote significant differences between the three distance categories included in the legend (there were no significant differences with distance for panels a and c). $* * *=P<0.001$, Grazing $=$ grazing occurrence 
(yes/no), Distance $=$ perpendicular distance from hedgerow,$M=$ month. Monthly means for each distance are presented with error bars showing the standard error of the mean $(n=3)$. The grey shaded box indicates period of drought.

701

Fig. 4. Monthly measurements of soil adjacent to a stone wall on free-draining soil for a) soil $\mathrm{CO}_{2}$ efflux, b) soil temperature and c) soil moisture at three perpendicular distances from the wall [0.7 $\mathrm{m}$ (grazed); $2 \mathrm{~m}$ (grazed); $10 \mathrm{~m}$ (grazed)]. The $\mathrm{r}^{2}$ value of the proportion of variation explained is given for the best-fit mixed effects model, with explanatory variable(s) listed underneath. For panel $b$, letters $(x, y, z)$ adjacent to lines denote significant differences between the three distance categories included in the legend (there were no significant differences with distance for panels a and c). ${ }^{* *}=P<0.01,{ }^{* * *}=P<0.001$, Distance $=$ perpendicular distance from wall. Grazing is not included as an explanatory variable as all distances are grazed. Monthly means for each distance are presented with error bars showing the standard error of the mean $(n=3)$. The grey shaded box indicates period of drought.

Fig. 5. Annual carbon $(C)$ budget schematic illustrating the estimated effect of hedgerows and livestock-grazed pasture on the C balance of both seasonally-wet (stagnogley) and freedraining (brown earth) soils. Annual soil $\mathrm{CO}_{2}$ efflux (SR) rates were calculated from monthly means (12 months inclusive) for the grazed (G) pasture and the un-grazed $(U)$ zone adjacent to the hedgerow (protected by the livestock-exclusion fences) and shown in the drought period-included $(\checkmark)$ sections of the schematic. Soil $\mathrm{CO}_{2}$ efflux for the drought period-excluded scenario ( $x$ ) was calculated from monthly means (July-April) but with field-measured soil $\mathrm{CO}_{2}$ efflux rates for the May-June drought period removed and replaced with modelled values (using the drought-excluded $\mathrm{Q}_{10}$ relationship) to give a 12 -month dataset. Proxies for aboveand below-ground net primary productivity (ANPP \& BNPP) were calculated from published 
data from the Conwy catchment. All figures are expressed in $\mathrm{C}_{2} \mathrm{ha}^{-1} \mathrm{yr}^{-1}$, with \pm standard error of the mean $(n=3)$ in parentheses. The symbols + and - denote a source of $\mathrm{CO}_{2}$ to the atmosphere and a sink (storage) of $\mathrm{CO}_{2}$ in plant biomass or soil respectively, with the values and arrows in black boxes indicative of net (plant + soil) ecosystem exchange. Methane and nitrous oxide fluxes are not included in these values.

Fig. 6. Change in $\mathrm{CO}_{2}$ flux estimate under projected increased hedgerow cover scenarios (based on a model 1-ha field) compared with a baseline of $100 \%$ pasture ( $0 \%$ hedgerow cover). Values for seasonally-wet (SW) versus free-draining (FD) soils under two drought period scenarios (included versus excluded) were extrapolated from a C balance calculated from published above- and below-ground net primary productivity (ANPP \& BNPP) for the

731 Conwy catchment and measured annual soil $\mathrm{CO}_{2}$ efflux rates to determine net $\mathrm{C}$ source / sink values (see Fig. 5). Hedgerow cover of $1 \%$ is equivalent to $50 \mathrm{~m} \mathrm{ha}^{-1}$ (double-fenced to exclude

733 livestock) at $2 \mathrm{~m}$ width, reflecting typical current UK hedgerow density. Hedgerow cover of $4 \%=200 \mathrm{~m} \mathrm{ha}^{-1}$ (at $2 \mathrm{~m}$ width), $8 \%=400 \mathrm{~m} \mathrm{ha}^{-1}$ (at $2 \mathrm{~m}$ width). Means for each hedgerow cover scenario are presented with error bars showing the standard error of the mean. 


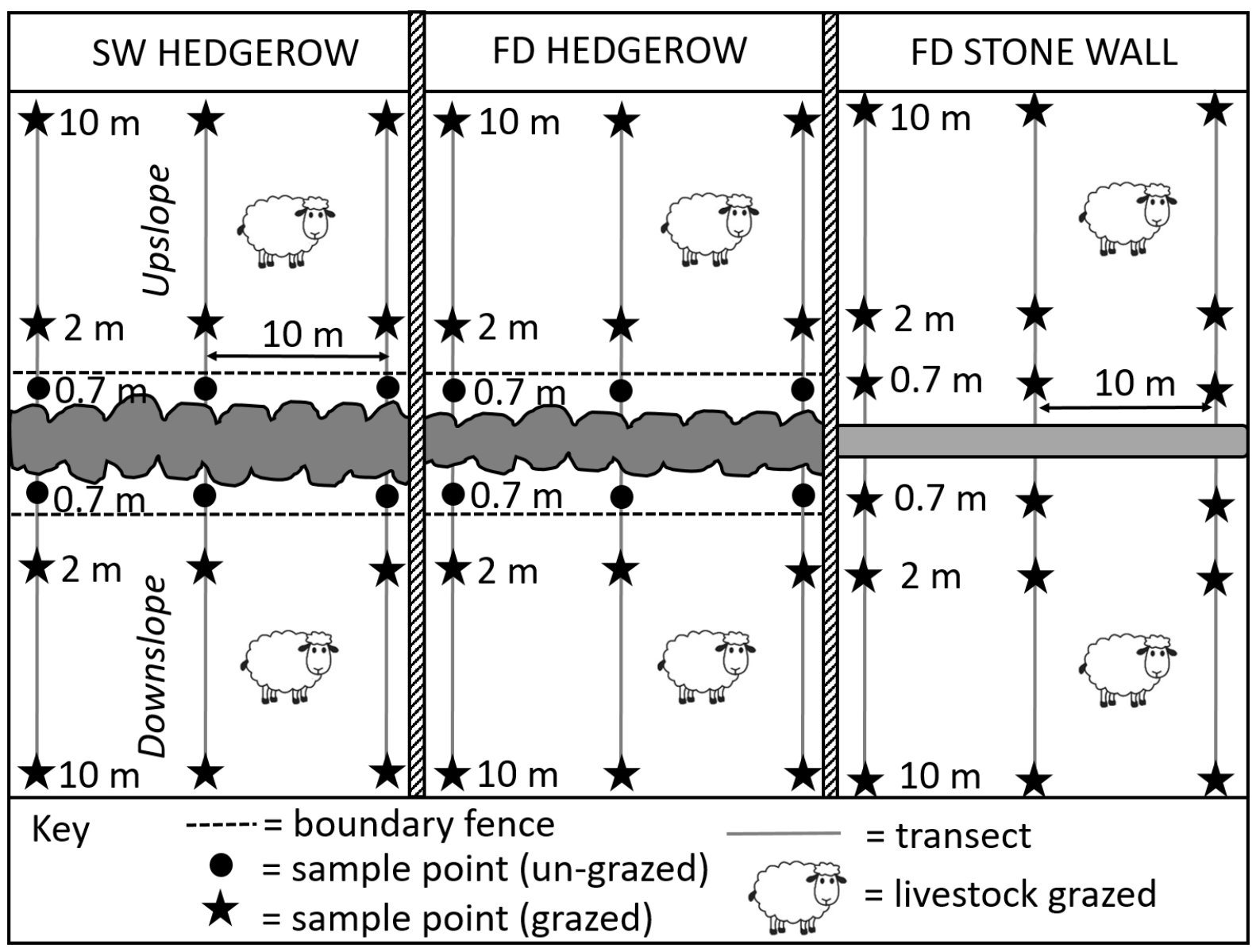

Fig. 1. 

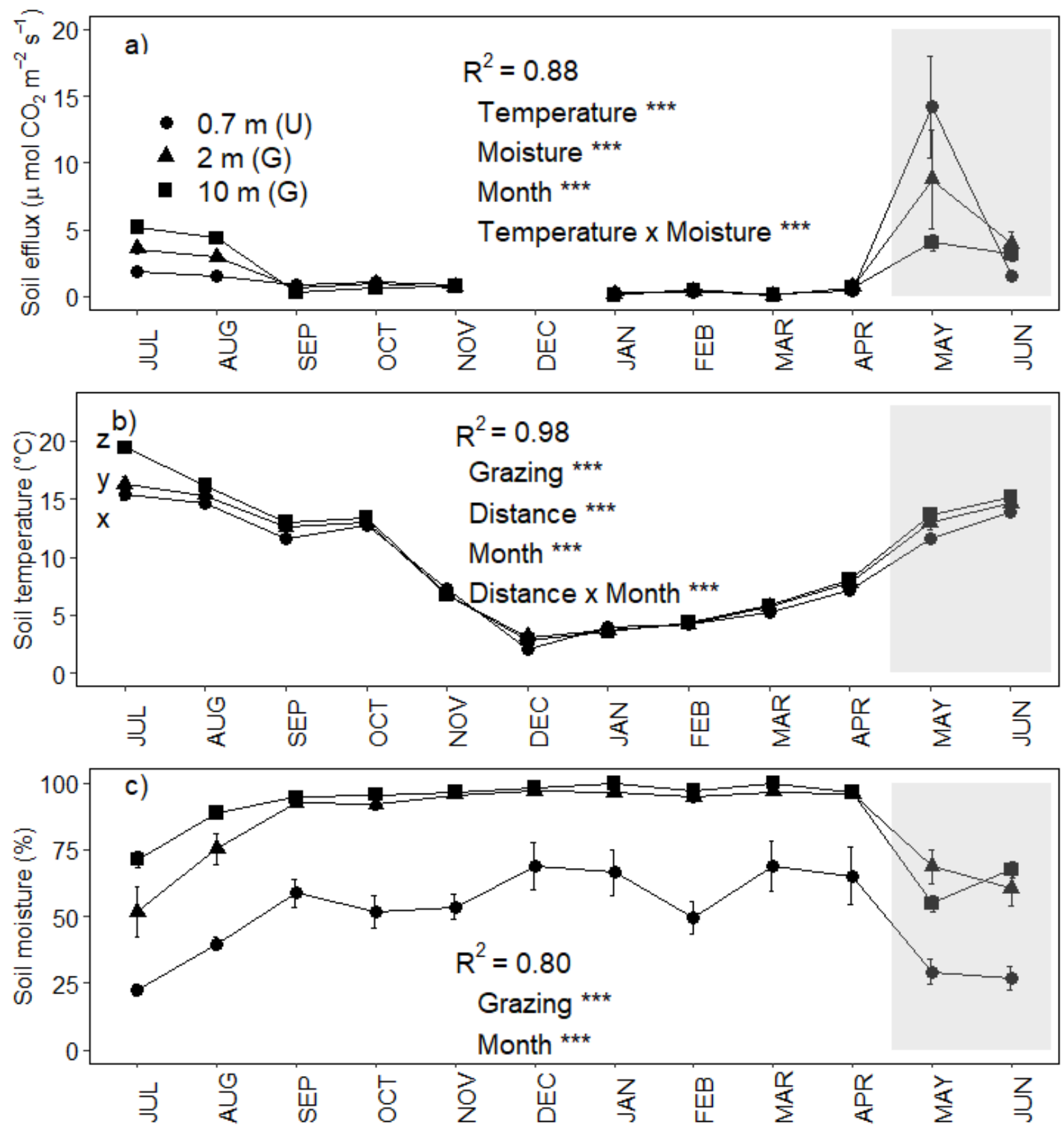

Fig. 2. 

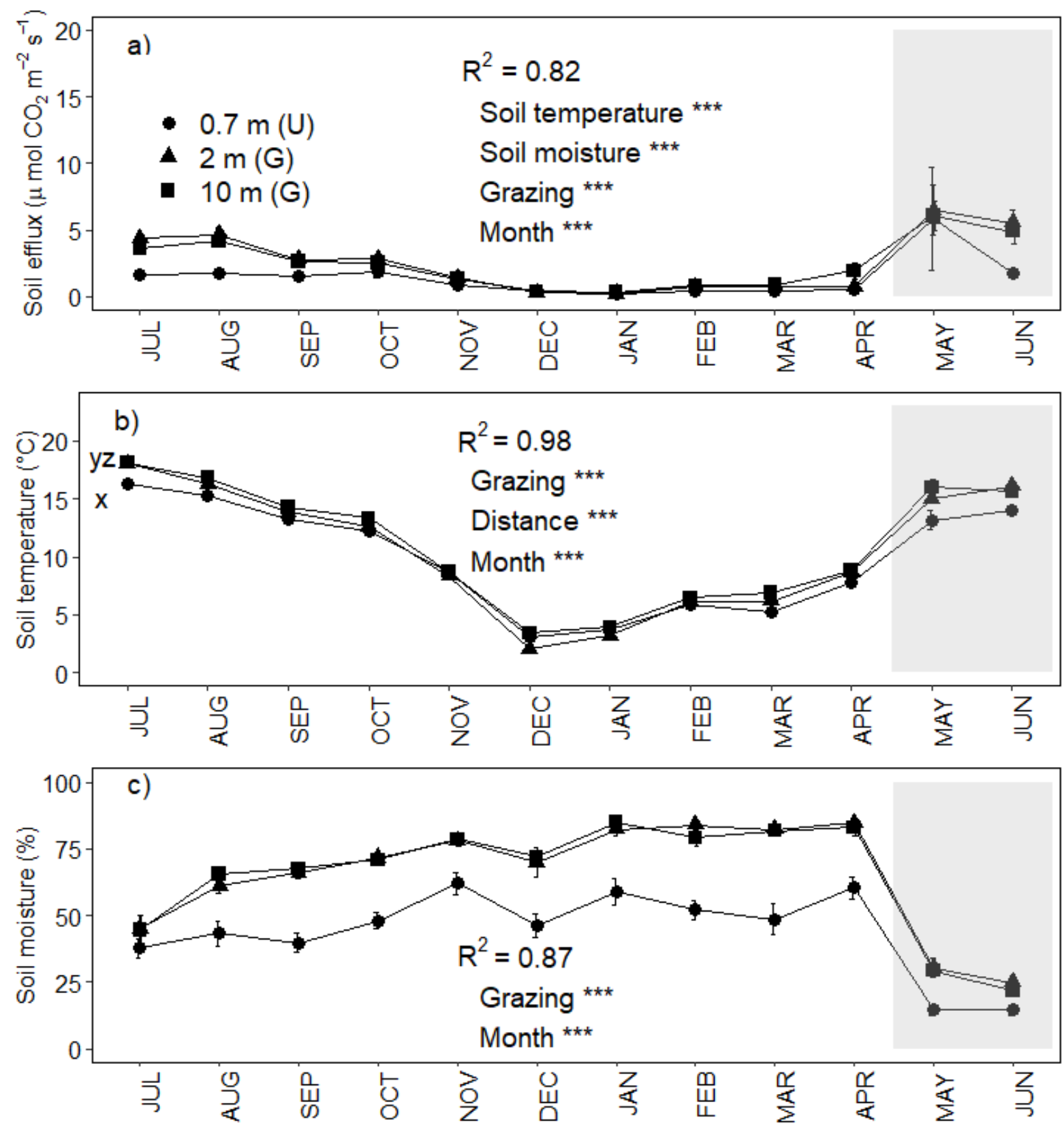

Fig. 3. 

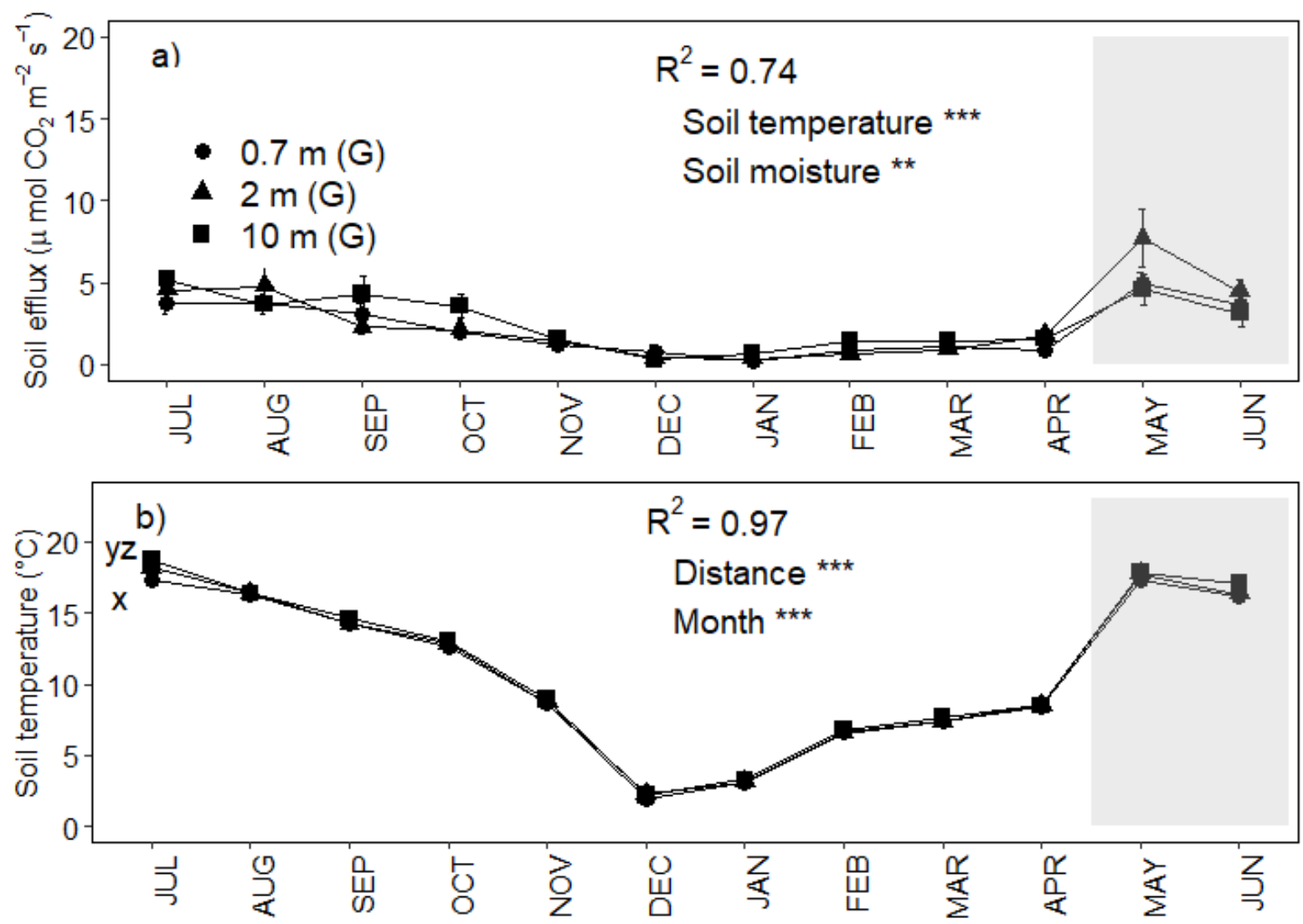

742

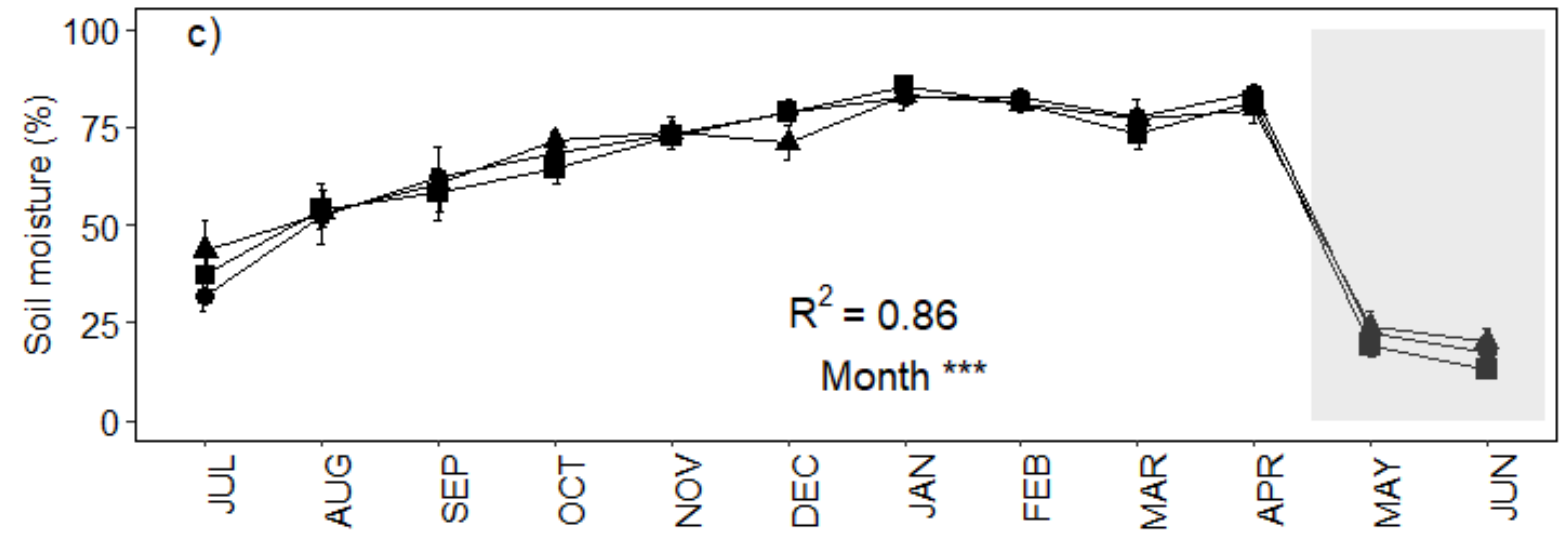

Fig. 4. 


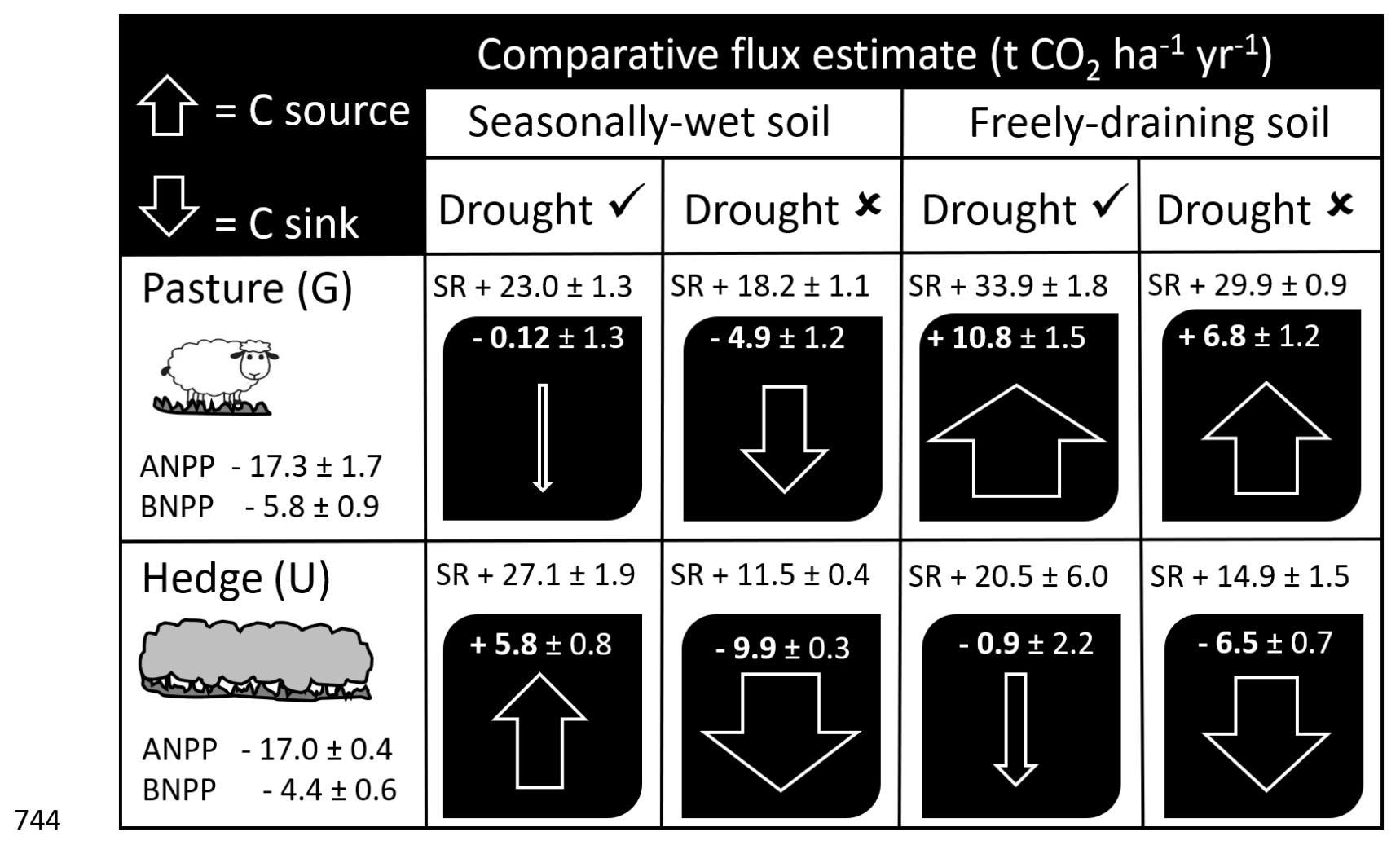

Fig. 5. 


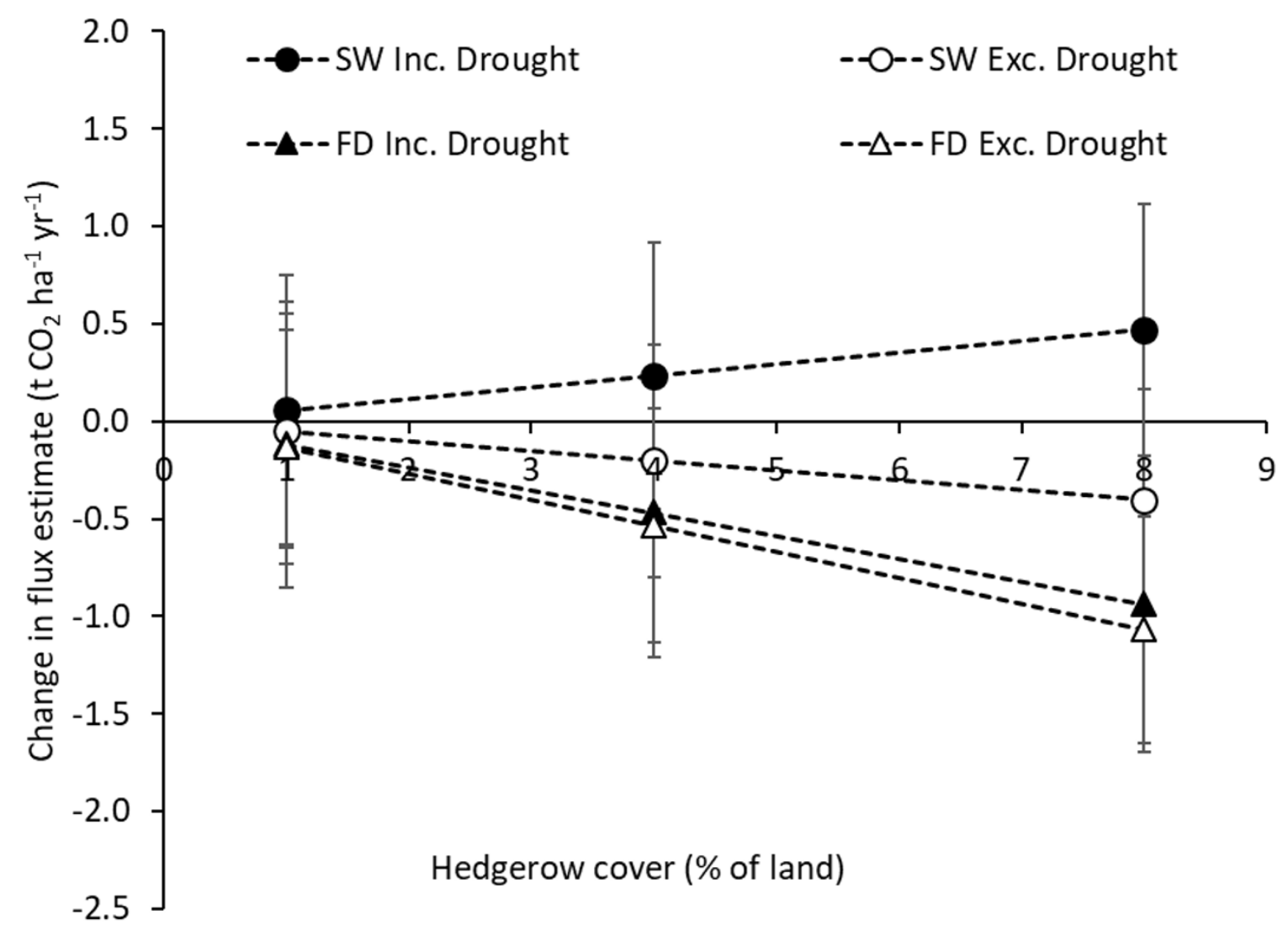

Fig. 6. 
Appendix.

Supplementary appendix for 'Hedgerow effects on $\mathrm{CO}_{2}$ emissions are regulated by soil type and season: implications for carbon flux dynamics in livestock-grazed pasture'.

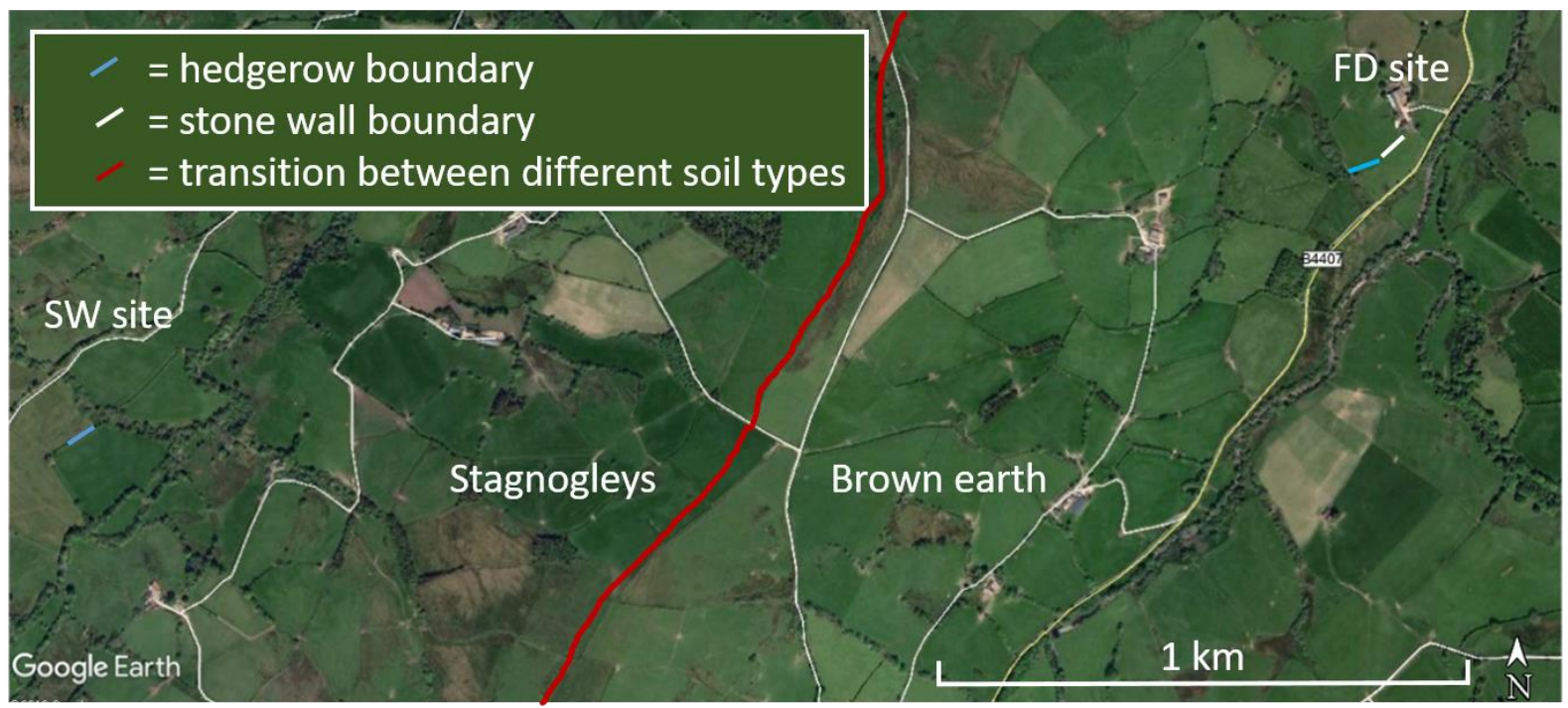

Fig. S1. Location of the two study sites and three field boundary categories used in this comparative observational study. FD site = site characterised by free-draining soil (brown earth), SW site = site characterised by seasonally-wet soil with impeded drainage (stagnogleys). Hedgerow boundaries (lines of trees) can be identified fairly easily from aerial images with stone wall and fence boundaries more difficult to distinguish. 